\title{
Phorbol Ester Degradation Using Biological Treatment in Jatropha Kernel Meal
}

\author{
Subarna Ghosh ${ }^{*}$ and Venkata S.P. Bitra \\ College of Agricultural Engineering, Bapatla, Guntur District, \\ Andhra Pradesh, India -522101 \\ *Corresponding author
}

\section{Keywords}

Detoxification, Oil expressed kernel meal, Pseudomonas aeruginosa

\section{Article Info}

Accepted: 10 April 2020 Available Online: 10 May 2020

\section{A B S T R A C T}

The presence of anti-nutritional factors in jatropha kernel meal such as, phorbol esters, lectins, trypsin inhibitor, phytate and saponins is of great concern. Toxicity of meal is mainly due to the presence of phorbol esters which limits its use. Several methods have been tried for detoxifying kernel meal that includes physical, chemical, biological and radiation methods. In the study, four different samples, i.e., raw, defatted, one-time mechanically oil expressed and two-times mechanically oil expressed samples were prepared from jatropha kernels. These samples were subjected to biological treatment for phorbol ester degradation. For biological treatment, strain Pseudomonas aeruginosa was used. Cell-free extract obtained from growing strains in a specific media was mixed with kernel meal samples to carry out detoxification. In biologically treated kernel meal, phorbol esters were found to be in range of $0.051-0.102 \mathrm{mg} / \mathrm{g}$ which was considered acceptable and hence, the treatment was found to be effective in phorbol ester degradation.

\section{Introduction}

Jatropha is an oilseed crop belonging to Euphorbiaceae family which has gained remarkable interest as a raw material for biodiesel industries. Jatropha seed contains approximately $30-35 \%$ oil that can be converted into high-quality biodiesel upon trans-esterification which can be used as a substitute for diesel fuel (Makkar and Becker, 2009). Presence of various anti-nutritional factors in the jatropha kernel meal (prepared using mechanical oil expellers) prevents its use as highly nutritiousprotein supplement in animal feed. The anti-nutritional factors are phorbol esters, lectin, trypsin inhibitor, phytate and saponins (Table 1) (Makkar et al., 1998; Makkar and Becker, 1997a). 
Jatropha kernel meal contains lignocelluloses and proteins in abundance and thus can be used advantageously as bio-fertilizer (Makkar et al., 1998) for production of biogas and as well as animal feed (Gubitz et al., 1998). But, toxic phorbol esters that are naturallyoccurring compounds are also present. Phorbol esters are widely distributed in plant species in the families of Euphorbiaceae and Thymelaeceae. They are tetracyclic diterpenoids of phorbol type and esters of tigliane diterpenes. Animal consumption of these phorbol esters can cause diarrhoea, inflammation of the gastrointestinal tract and death. If jatropha kernel meal is detoxified, it could be an excellent protein source. Several methods have been tried for detoxifying kernel meal that includes physical, chemical and biological methods (Ahluwalia et al., 2017a).

Some researchers (Azhar et al., 2014; Chang et al., 2014; Xing et al., 2013) employed biological detoxification methods by the use of fungi and bacteria for detoxifying jatropha seed cake by solid state fermentation process. Bacterialcultures may reduce the detoxification time which can make the process rapid and economical. Also, biodetoxification does not involve the application of any chemicals or mixtures and taking into consideration the safety and energy concerns; the biological methods are more advantageous than the others. But, at the same time, biodetoxification may be inconvenient and timeconsuming (de Barros et al., 2011; Belewu and Sam, 2010).

This study was carried out to find the effects of biological treatment on phorbol ester degradation in jatropha kernel meal. This kind of research is of great importance so as to incorporate jatropha kernel meal in commercially produced aqua-feeds after evaluating the toxicity levels of treated jatropha kernel meal. Keeping in view, the present work was conducted with the following specific objectives include to study the effect of biological treatment on phorbol ester degradation in jatropha kernel meal and to estimate phorbol ester contentin the kernel meal after treatment

\section{Materials and Methods}

Jatropha seeds were obtained from Samarlakota, East Godavari District, Andhra Pradesh. Seed coat was removed mechanically using castor sheller adjusted suitably to obtain kernels. Four different jatropha kernel meal samples were prepared, namely, a) raw, b) defatted (solvent extracted), c) one-time mechanically oil expressed and d) two-times mechanically oil expressed. Jatropha kernels were size reduced in Wiley mill (Ultra Lab Instruments, New Delhi) using 20 mesh screen $(850 \mu \mathrm{m})$ for preparing raw sample. This 20 mesh raw sample was oil extracted with automatic Soxhlet apparatus using petroleum ether (boiling point: $65^{\circ} \mathrm{C}$ ) as solvent to produce defatted sample. Mechanical oil expression of jatropha kernels was done using mechanical mini oil expeller (Rajkumar Agro Engineers Pvt. Ltd., Nagpur) to obtain one-time mechanically oil expressed sample and twotimes mechanically oil expressed sample. It is to be noted that the defatted sample was without oil in it. All the prepared samples were stored at $4{ }^{\circ} \mathrm{C}$ in a refrigerator till treatment was carried out (Fig. 1).

\section{Biological treatment}

Biological treatment was done as reported by Ahluwalia et al., (2017b) using submerged fermentation method. This method was adopted because it reported treatment time of $15 \mathrm{~h}$ which was very short treatment time as compared to other methods. Also, submerged fermentation method results in more toxins degradation than solid-state fermentation 
(Phengnuam and Suntornsuk, 2013).

\section{Culture}

Culture media were procured from Department of Microbiology, University of Pondicherry, Pondicherry. Strain Pseudomonas aeruginosa obtained from soil samples was used for detoxification.

\section{Preparation of inoculum}

Culture was first grown in nutrient broth. Nutrient broth $(1.3 \mathrm{~g})$ was dissolved in 100 $\mathrm{mL}$ of distilled water in a conical flask which was autoclaved at $15 \mathrm{psi}\left(103.4 \mathrm{kN} / \mathrm{m}^{2}\right)$ for 15 min. Flask was cooled and transferred to laminar flow chamber. Exactly $0.1 \mathrm{~mL}$ of the Pseudomonas aeruginosa strain was added to the broth and kept in incubator shaker at 37 ${ }^{\circ} \mathrm{C}$ and $100 \mathrm{rpm}$ for $24 \mathrm{~h}$.

Strain was allowed to grow in petri-dishes to obtain inoculum. For this, $2.8 \mathrm{~g}$ of agar was added to $100 \mathrm{~mL}$ distilled water and autoclaved for $15 \mathrm{~min}$. Three petri-dishes were also autoclaved. After cooling, petridishes and agar solution were transferred to laminar flow chamber, where approximately $10 \mathrm{~mL}$ of agar solution was poured into each petri dish and allowed to solidify. Approximately $0.1 \mathrm{~mL}$ of strain which was grown in nutrient broth was spread over solidified agar in petri-dishes which were kept in incubator at $37^{\circ} \mathrm{C}$ for $24 \mathrm{~h}$ for strains to grow.

About $1 \%$ of prepared culture stated as above was used to inoculate the media containing starch (2\%), $\mathrm{KH}_{2} \mathrm{PO}_{4}(0.5 \%), \mathrm{KNO}_{3}(1.01 \%)$, $\mathrm{NH}_{4} \mathrm{Cl}(0.535 \%), \mathrm{MgSO}_{4} .7 \mathrm{H}_{2} \mathrm{O}(0.001 \%)$, $\mathrm{CaCl}_{2} .2 \mathrm{H}_{2} \mathrm{O} \quad(0.01 \%)$ and $\mathrm{Na}_{2} \mathrm{HPO} .12 \mathrm{H}_{2} \mathrm{O}$ $(0.8 \%)$. Incubation was done in a rotary shaker at $37{ }^{\circ} \mathrm{C}$ for $24 \mathrm{~h}$ at $100 \mathrm{rpm}$ and was centrifuged at $10000 \mathrm{~g} \mathrm{rpm}$ for $20 \mathrm{~min}$ at $4{ }^{\circ} \mathrm{C}$ using refrigerated centrifuge (Model: $\mathrm{C}-24$
Plus; Remi Laboratory Instruments, Mumbai) for obtaining a cell-free supernatant. Enzymes present in the cell-free supernatant were responsible for detoxification of jatropha kernel meal samples.

\section{Submerged fermentation of jatropha kernel meal}

Exactly $5 \mathrm{~g}$ of kernel meal was added to the cell-free supernatant and incubated in a rotary shaker at $37{ }^{\circ} \mathrm{C}, \mathrm{pH} 7,100 \mathrm{rpm}$ for $15 \mathrm{~h}$ to undergo submerged fermentation. Experiment was replicated thrice. Mixture of kernel meal and cell-free supernatant was filtered and kept in hot air oven at $37{ }^{\circ} \mathrm{C}$ for $48 \mathrm{~h}$ to obtain dried kernel meal. Microbiologically treated jatropha kernel meal samples are shown in Fig.2.

\section{Estimation of phorbol esters}

Phorbol esters were determined according to the modified method of Haas and Mittelbach (2000) proposed by Saetae and Suntornsuk (2010).

Jatropha curcas kernel meal samples (5 g) were ground by using a blender and poured into flasks containing $20 \mathrm{~mL}$ of methanol. Mixture of kernel meal and methanol was stirred by using a shaker operated at $250 \mathrm{rpm}$ for $5 \mathrm{~min}$. It was then filtered using a Whatman No. 4 filter paper and vacuum pump. Residue on the filter paper and the extract were collected. This process was repeated and the residue was extracted four additional times. The extract fractions from all five extractions were combined and dried under vacuum at $40{ }^{\circ} \mathrm{C}$ using a vacuum oven. The dried extract was dissolved in $5 \mathrm{~mL}$ of methanol and passed through a $0.2-\mu \mathrm{m}$ membrane filter (ChroMex, U.K.). Exactly 20 $\mu \mathrm{L}$ of extract solution was analyzed for phorbol esters by HPLC (Model 1100; Agilent, USA). 
HPLC analytical column used was a $150 \times 3.9$ mm ID, 4- $\mu \mathrm{m}$ particle size, Nova-Pak C18 (Waters, Ireland), with a SBC18 guard column $(12.5 \times 4.6 \mathrm{~mm} \mathrm{ID}), 5-\mu \mathrm{m}$ particle size (Agilent, USA). The column was thermally controlled at $25^{\circ} \mathrm{C}$. A mixture of acetonitrile (HPLC grade; Fisher Scientific, U.K.) and deionized water in the ratio of 80:20 (v:v) was used as the mobile phase at a flow rate of 1 $\mathrm{mL} / \mathrm{min}$. The detector wavelength was set at $254 \mathrm{~nm}$. Results were expressed as equivalent to phorbol-12-myristate-13-acetate (PMA) (Sigma, U.K.) used as an external standard. The PMA was dissolved in methanol (Fisher Scientific, U.K.) for preparation of standard curve.

\section{Statistical analysis}

Statistical analysis was carried out using oneway ANOVA in Microsoft Excel. Statistical significance of phorbol ester content in raw, defatted, one-time and two-times mechanically oil expressed samples before and after treatment was analyzed at $\mathrm{p}<0.05$.

\section{Results and Discussion}

\section{Phorbol esters content before treatment}

Phorbol ester content was analyzed for raw, defatted, one-time and two-times mechanically oil expressed kernel meal before treatment. The phorbol ester content was $0.901 \mathrm{mg} / \mathrm{g}$ of kernel meal for raw sample, whereas it reduced to $0.250 \mathrm{mg} / \mathrm{g}$ of kernel meal for defatted sample (Fig. 3). One-time and two-times mechanically oil expressed samples showed phorbol ester content of 0.458 and $0.350 \mathrm{mg} / \mathrm{g}$ of kernel meal.

Phorbol esters reduced in mechanically expressed and defatted samples because of extraction of oil. During mechanical extraction of oil from seeds, $70-75 \%$ of PE comes out with oil, but the rest are still retained in the kernel meal, thus making both the meal and oil inedible (Devappa et al., 2012). Thus, with decrease in oil content PE content also decreased (Fig. 4). Statistical analysis by ANOVA showed no significant difference in PE content $(\mathrm{p}<0.05)$.

\section{Phorbol ester content after biological treatment}

Effect of biological treatment on PE content of raw, defatted, one-time and two-times mechanically oil expressed sample was analyzed. PE content reduced for all the cases (Fig. 5) when compared with the untreated samples (Fig. 3).

PE content reduced to 0.102 and $0.051 \mathrm{mg} / \mathrm{g}$ of kernel meal for raw and defatted samples, respectively. One-time and two-times mechanically expressed samples showed PE content of 0.072 and $0.055 \mathrm{mg} / \mathrm{g}$ of kernel meal, respectively. PE content of biologically treated raw, defatted, one-time and two-times mechanically oil expressed samples decreased by $88.68 \%, 79.60 \%, 84.28 \%$ and $84.29 \%$, respectively, compared to untreated samples (Table 2).

Acceptable limit of PE content for food and feed purposes is $0.11 \mathrm{mg} / \mathrm{g}$ (Makkar and Becker, 1997). PE content in biologically treated samples was less than the acceptable limit. Hence, biologically treated jatropha kernel meal can be used in food or feed.

In conclusion, study on phorbol ester degradation using biological treatment in jatropha kernel meal was done to find the effectiveness of the treatment to detoxify jatropha kernel meal. Toxin content was also determined to ensure its suitability in food or feed purposes. Biological treatment involved fermentation with the strain Pseudomonas aeruginosa. Treatment was done for $15 \mathrm{~h}$ at $37{ }^{\circ} \mathrm{C}, \mathrm{pH} 7$ and $100 \mathrm{rpm}$ in an incubator shaker. Phorbol ester content was found to be 
high in untreated samples and was not within acceptable limits. Biological treatment was found to be effective in reduction of phorbol esters. Phorbol esters in biologically treated kernel meal was lower than untreated samples and was observed to be $0.102 \mathrm{mg} / \mathrm{g}$ for raw sample and $0.051 \mathrm{mg} / \mathrm{g}$ for defatted sample whereas, 0.072 and $0.055 \mathrm{mg} / \mathrm{g}$ for one-time and two-times mechanically expressed samples and they reduced by $88.68 \%$, $79.60 \%, 84.28 \%$ and $84.29 \%$, respectively.

Table.1 Anti-nutritional components in jatropha kernel meal

\begin{tabular}{|l|c|c|c|}
\hline \multirow{2}{*}{$\begin{array}{l}\text { Toxic and Anti- } \\
\text { Nutritional Compound }\end{array}$} & $\begin{array}{c}|c| \\
\text { Cape Verde } \\
\text { (Highly Toxic) }\end{array}$ & $\begin{array}{c}\text { Nicaragua } \\
\text { (Highly Toxic) }\end{array}$ & $\begin{array}{c}\text { Mexican } \\
\text { (Non-Toxic) }\end{array}$ \\
\hline Phorbol ester (mg/g kernel) & 2.70 & 2.17 & 0.11 \\
\hline Lectin (mg/g kernel) & 102.00 & 102.00 & 51.00 \\
\hline $\begin{array}{l}\text { Trypsin inhibitor activity(mg inhibition/ } \\
\text { g kernel meal) }\end{array}$ & 21.30 & 21.10 & 26.50 \\
\hline Phytate (\% in kernel meal) & 9.40 & 10.10 & 8.90 \\
\hline $\begin{array}{l}\text { Saponin (\% diosgenin eqv. in kernel } \\
\text { meal) }\end{array}$ & 2.60 & 2.00 & 3.40 \\
\hline
\end{tabular}

Table.2 Per cent reduction in phorbol esters due to biological treatment over untreated samples

\begin{tabular}{|l|c|}
\hline \multicolumn{1}{|c|}{ Sample } & Per cent Reduction \\
\hline Raw & 88.68 \\
\hline Defatted & 79.60 \\
\hline $\begin{array}{l}\text { One-time mechanically oil } \\
\text { expressed }\end{array}$ & 84.28 \\
\hline $\begin{array}{l}\text { Two-times mechanically oil } \\
\text { expressed }\end{array}$ & 84.29 \\
\hline
\end{tabular}



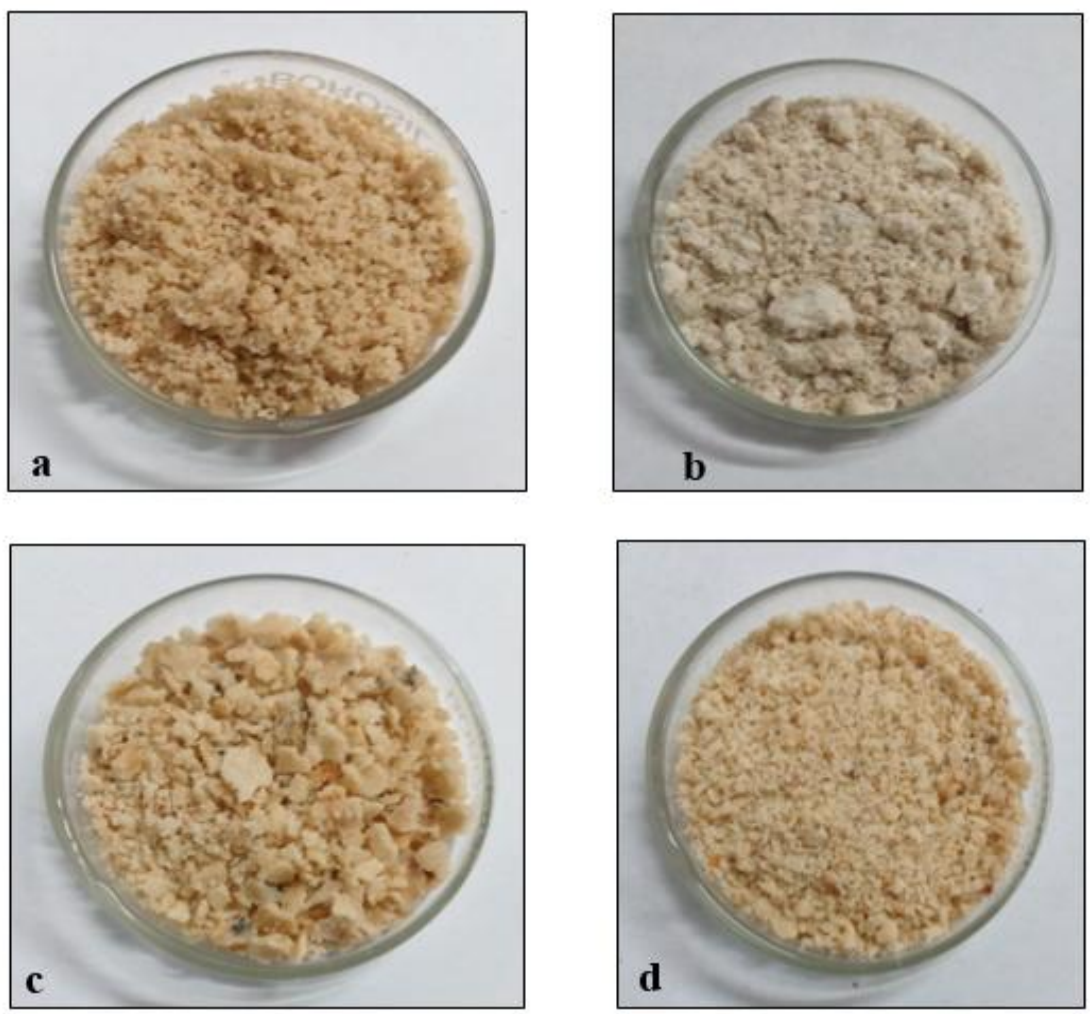

Fig.1 Jatropha kernel meal samples before treatment a) Raw, b) Defatted, c) One-time mechanically oil expressed and d)Two-times mechanically oil expressed
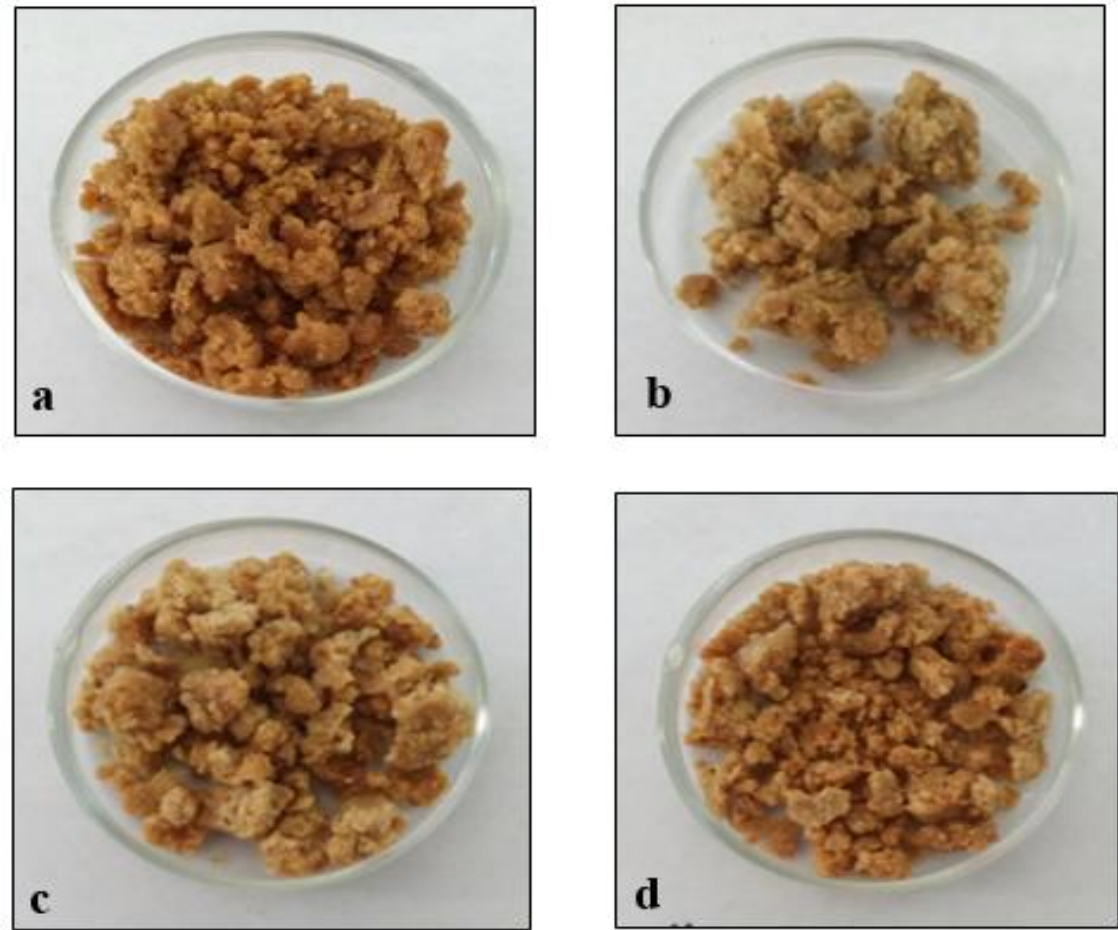

Fig.2 Microbiologically treated jatropha kernel meal samples a) Raw, b) Defatted, c) One-time mechanically oil expressed and d) Two-times mechanically oil expressed 


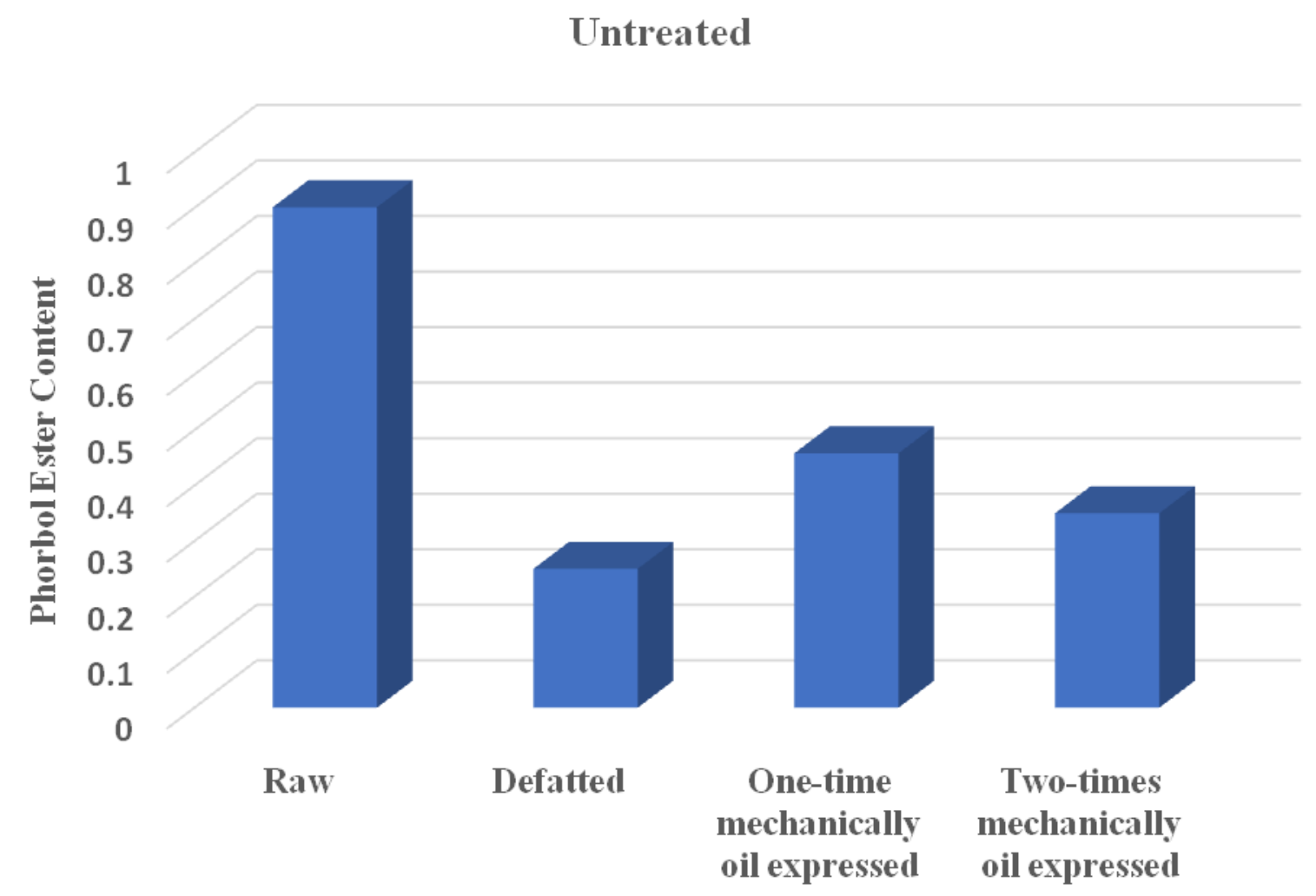

Fig.3 Phorbol ester content before biological treatment

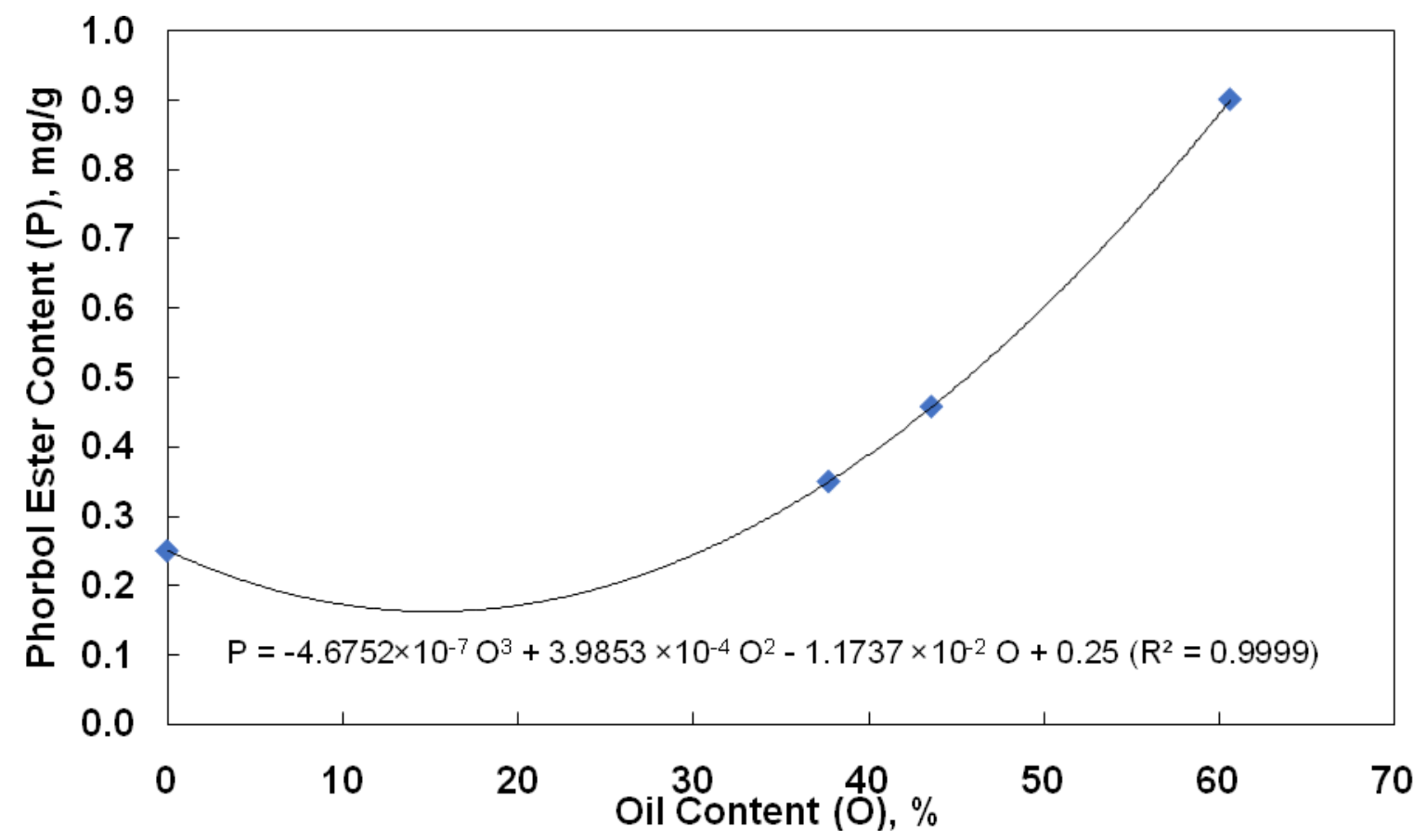

Fig.4 Variation of phorbol ester content with oil content 


\section{Biological Treatment}

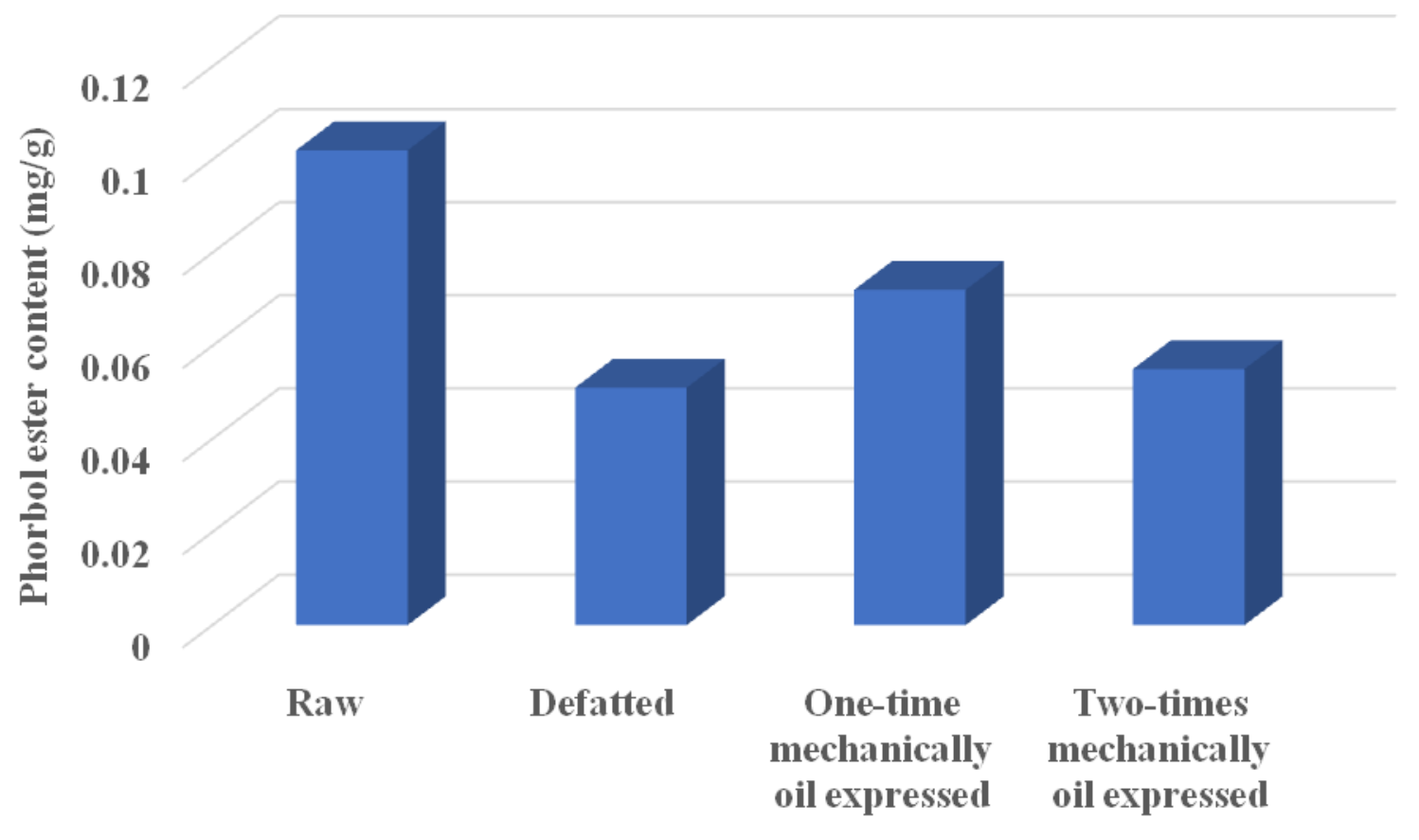

Fig.5 Phorbol ester content after biological treatment

\section{References}

Ahluwalia, S., Bidlan, R., Sharma, J.G. and Singh, P. 2017a. Review on phorbol ester degradation of jatropha seed cake for its use as animal feed. International Journal of Pharmacy and Pharmaceutical Sciences. 9(1): 7-13.

Ahluwalia, S., Sharma, J.G. and Singh, P. 2017b. Degradation of phorbol esters in jatropha seed cake by Pseudomonas aeruginosa DS1. International Journal of Pharma and Bio Sciences. 8(2): 542546.

Azhar, N., Norhani, A., Wan, Z., Syahida, A., Ehsan, O. andFaridah, A. 2014. Detoxification of toxic phorbol esters from Malaysian Jatropha curcas Linn. kernel by Trichoderma spp. and endophytic fungi. International Journal of Molecular Sciences. 15:2274-2288.

Belewu, M.A. and Sam, R. 2010. Solid state fermentation of Jatropha curcas kernel cake: proximate composition and antinutritional components. Journal of Yeast and Fungal Research. 1:44-46.

Chang, C.F., Weng, J.H., Lin, K.Y., Liu, L.Y. and Yang, S.S. 2014. Phorbol esters degradation and enzyme production by Bacillus using jatropha seed cake as substrate. International Journal of Environmental Pollution and Remediation. 2:30-36.

de Barros, C.R.M., Ferreira, M.M.L., Nunes, F.M., Bezerra, R.M.F., Dias, A.A. and Guedes, C.V. 2011. The potential of white-rot fungi to degrade phorbol esters of Jatropha curcas L. seed cake. Engineering in Life Science. 11:107110.

Devappa, R.K., Makkar, H.P.S. and Becker, K. 2012. Localisation of anti-nutrients and qualitative identification of toxic components in Jatropha curcas seed. Journal of the Science of Food and Agriculture. 92: 1519-1525. 
Gubitz, G.M., Mittelbach, M. and Trabi, M. 1998. Exploitation of the tropical oil seed plant Jatropha curcas L. Bioresource Technology. 67: 73-82.

Haas, W., Sterk, H. and Mittlebach, M. 2002. Novel 12-deoxy-16-hydroxyphorbol diesters isolated from the seed oil of Jatropha curcas.Journal of Natural Products. 65: 1434-1440.

Makkar, H.P.S., Aderibigbe, A.O. and Becker, K. 1998. Comparative evaluation of non-toxic and toxic varieties of Jatropha curcas for chemical composition, digestibility, protein degradability and toxic factors. Food Chemistry. 62(2): 207-215.

Makkar, H.P.S. and Becker, K. 1997. Potential of $J$. curcas seed meal as a protein supplement to livestock feed, constraints to its utilisation and possible strategies to overcome constraints. In: Gubitz, G.M., Mittelbach, M. and Trabi, M. (Eds.) Biofuels and Industrial Products from Jatropha curcas.
Dubrovnik, Graz. pp. 190-205.

Makkar, H.P.S. and Becker, K. 2009. Jatropha curcas, a promising crop for the generation of biodiesel and value-added coproducts. European Journal of Lipid Science and Technology. 111: 773-787.

Phengnuam, T. and Suntornsuk, W. 2013. Detoxification and anti-nutrients reduction of Jatropha curcas seed cake by Bacillus fermentation. Journal of Bioscience and Bioengineering. 115(2): 168-172.

Saetae, D. and Suntornsuk, W. Antifungal activities of ethanolic extract from Jatropha curcasseed cake. 2010. Journal of Microbiology and Biotechnology. 20(2): 319-324.

Xing, H.W., Lingcheng, O., Liang, L.F., Shui, Z., Ji-Dong, L.G.L. and Jiao, L. 2013. Detoxification of Jatropha curcas kernel cake by a novel Streptomyces fimicarius strain. Journal of Hazardous Materials. 260: 238-246.

\section{How to cite this article:}

Subarna Ghosha and Venkata S.P. Bitra. 2020. Phorbol Ester Degradation Using Biological Treatment in Jatropha Kernel Meal. Int.J.Curr.Microbiol.App.Sci. 9(05): 1449-1457. doi: https://doi.org/10.20546/ijcmas.2020.905.165 